\title{
Four semesters of medical humanities at the Xavier University School of Medicine, Aruba
}

\author{
P.R. Shankar \\ Professor of Pharmacology, Chair, Curriculum Committee, Xavier University School of Medicine, Oranjestad, Aruba, \\ Kingdom of the Netherlands
}

Introduction: Medical humanities is using subjects traditionally known as the humanities for specific purposes in medical education. Methods: In this report the author shares his experience of facilitating a module for four semesters at the Xavier University School of Medicine, Aruba. Results: The sessions were conducted in small groups and used case scenarios, role-plays, paintings and debates among other modalities to explore various aspects of medical humanities. Conclusion: The author has been successful in conducting Access this article online Website:

http://nepjol.info/index.php/AJMS

DOI: $10.3126 / a j m s . v 6 \mathrm{i} 2.10455$ medical humanities sessions in an offshore Caribbean medical school.

Key words: Caribbean, medical humanities, medical students, small groups

Medical humanities $(\mathrm{MH})$ is using subjects traditionally known as the humanities for specific purposes in medical education. I had initiated MH modules in two medical schools in Nepal and have been involved with the discipline for over seven years. ${ }^{1,2}$

Xavier University School of Medicine (XUSOM) is a private medical school in Aruba, Kingdom of the Netherlands admitting students mainly from the United States of America and Canada to the undergraduate medical (MD) course. From January 2013 the school has shifted to an integrated organ system-based curriculum and small group learning is actively encouraged. ${ }^{3}$ At XUSOM a semester is of 15 weeks duration and there are three student intakes in January, May and September.

A medical humanities $(\mathrm{MH})$ module is being offered to all first semester students from January $2013 .{ }^{4}$ The module is conducted in small groups over a ninety minute period and uses case scenarios, role-plays, interpretation of paintings and debates to explore various aspects of $\mathrm{MH}$.

The module is in accordance with the school's mission of producing leaders in primary care medicine and links well with the objectives of understanding the social context of medicine, developing good communication skills, and inculcating professionalism among students. Among the topics covered are an introductory session, empathy, what it means to be sick, the patient, the doctor, the patient-doctor relationship, and the medical student. Table 1 shows the learning objectives of different sessions.

The session usually starts with a general introduction by the facilitators to the topic, and a general discussion about various issues related to the topic with inputs from both students and facilitators. This is followed by various activities where students work in small groups with support and guidance from the facilitators. Certain role play scenarios were partly modified from those developed for use in modules conducted in $\mathrm{Nepal}^{1,2}$ while others were newly created. The transcripts of student role-plays from KIST Medical College, Nepal have been described in two recent articles., ${ }^{5,6}$ Table 2 details the role-play scenarios used during the module. Over the course of the module I realized that certain aspects were different but many other themes were universal. Role-plays are increasingly being used in undergraduate medical education. In a medical school in Pakistan students had a positive perception regarding role-plays as a teaching-learning methodology and regarded these as the most effective method of teaching. ${ }^{7}$ Respondents found role-plays interesting, and 


\begin{tabular}{|c|c|}
\hline Session & Learning objectives \\
\hline Introductory session & $\begin{array}{l}\text { At the end of this session students will be: } \\
\text { - Familiar with each other and the facilitator and } \\
\text { - Introduced to working in small groups and } \\
\text { - Aware of the medical humanities }\end{array}$ \\
\hline Empathy & $\begin{array}{l}\text { At the end of this session students will be able to: } \\
\text { - Understand the concept of empathy and compare and contrast it with sympathy } \\
\text { - Discuss possible reasons for decline of empathy today } \\
\text { - Enumerate professions where empathy is important and } \\
\text { - Mention methods of enhancing empathy in professional \& personal life }\end{array}$ \\
\hline What it means to be sick? & $\begin{array}{l}\text { At the end of this session students will be able to: } \\
\text { - Understand what it means to be sick } \\
\text { - Explore certain specific instances of being sick in more detail } \\
\text { - List various problems/aspects of being sick }\end{array}$ \\
\hline The patient & $\begin{array}{l}\text { At the end of this session students will be able to: } \\
\text { - Reflect on individual experiences of sickness } \\
\text { - Understand illness and disability from a patient perspective }\end{array}$ \\
\hline The doctor & $\begin{array}{l}\text { At the end of this session students will be able to: } \\
\text { - Obtain a perspective on what it means to be a doctor } \\
\text { - Explore balancing a meaningful personal life with a busy and rewarding professional career } \\
\text { - Understand 'certain' influences and pressures on a doctor today } \\
\text { - Interpret the changing role of doctors through paintings and stories }\end{array}$ \\
\hline The patient-doctor relationship & $\begin{array}{l}\text { At the end of this session students will be: } \\
\text { - Familiar with the changing perspective of the patient-doctor relationship } \\
\text { - Analyze certain important issues in the patient-doctor relationship and } \\
\text { - List certain methods to make the patient-doctor relationship more patient-centered and egalitarian } \\
\text { - Familiar with the patient-doctor relationship in developed and developing nations } \\
\text { - Understand future trends in the patient-doctor relationship } \\
\text { - Interpret the evolving nature of the relationship through paintings }\end{array}$ \\
\hline The medical student & $\begin{array}{l}\text { At the end of the session participants will be: } \\
\text { - Able to reflect on what it means to be a medical student in the twenty-first century } \\
\text { - Able to explore certain facets of medical student life } \\
\text { - Aware of stress and its effects on medical education } \\
\text { - Aware of the knowledge explosion in medicine and methods of coping } \\
\text { - Interpret art dealing with a medical student perspective }\end{array}$ \\
\hline
\end{tabular}

were of the opinion that it improved their communication skills, awareness of the local situation and promoted critical thinking. In a German medical school role-plays were among the various learning strategies found suitable to communicate topics like breaking bad news. ${ }^{8}$ Role-plays promote active learning and are effective if the learning objectives are well defined, and the cases challenging. ${ }^{9}$

Most paintings used during the module were obtained from the literature, arts and medicine database (http://litmed. med.nyu.edu/Main?action=new) maintained by New York University. Among the various paintings which I had used during the module were 'The doctor' by Sir Luke Fildes, 'The death of Socrates' by Jacques-Louis David, 'City hospital' by Alice Neel, and 'The paralytic' by Jean-Baptiste Greuze during the empathy session. The paintings 'Tree of hope' by Frieda Kahlo and 'Goya attended by Dr Arrieta' by Francisco Goya were used during the session on 'The patient' while 'Laennec Listening with his Ear Against the Chest of a Patient at the Necker Hospital' by Chartran Theobold, 'The Agnew clinic' by Thomas Eakins and 'The anatomy lesson of Nicolaes Tulp' by Rembrandt were used during the session dealing with the doctor. During the session dealing with 'The patient-doctor relationship' the paintings used were 'Doctor and doll' by Norman Rockwell, and 'Science and charity' by Pablo Picasso. Many of these paintings were similar to those used during the $\mathrm{MH}$ modules in KIST Medical College, Nepal. ${ }^{10}$

At the school, Medical Humanities is a part of Patient, Doctor, and Society (PDS) for the first semester. PDS is a course which is offered to students through all semesters of basic science education and has the objective of helping students communicate better with patients and at the same time also enhance their understanding of scientific literature and prepare them for self-directed learning. PDS includes different course like introduction to study of medicine (ISM), clinical epidemiology, family health visits, early clinical exposure and critical appraisal of scientific literature. The ISM sessions address a variety of topics like leadership skills, history of medicine, being a primary care physician in the United States, among others. Students get opportunities to develop their team working and leadership skills through various student organizations in the school, health fairs, problem-based learning sessions and family health visits. Students 


\section{Table 2: Role-plays used during the module}

\begin{tabular}{|c|c|}
\hline Session & Role-plays \\
\hline $\begin{array}{l}\text { What it means to } \\
\text { be sick? }\end{array}$ & $\begin{array}{l}\text { - Mr. Antony is a poor immigrant from the Dominican Republic living in Brooklyn, New York. His two year old son } \\
\text { has been suffering from diarrhea since the last two days. The family is uneducated and believes that if water is } \\
\text { given during diarrhea it would be lost in the stools. The boy, Andreas has not been given anything by mouth since } \\
\text { two days. He is extremely weak, stupurous and dehydrated. Explore what it means to be sick using a role-play. } \\
\text { - Ms. Mohini is a } 28 \text { year old lady from South Asia who was trafficked and was compelled to become a } \\
\text { commercial sex worker. After ten years of service she was sent back to her country and village as she became } \\
\text { HIV positive. The disease is at an advanced stage and she has no money for treatment. Her family has } \\
\text { reluctantly allowed her to stay with them but is not happy that a retired prostitute is living with them. Explore } \\
\text { what it means to be sick using a role-play. }\end{array}$ \\
\hline The patient & $\begin{array}{l}\text { Richard Demetrios is a } 30 \text { year old man who has been diagnosed to be suffering from HIVIAIDS. He lives in } \\
\text { northern California and is the owner of a night club. On learning that he is suffering from HIVIAIDS his wife has } \\
\text { left him taking with her their children. She has accused him of having intimate relations with the exotic dancers } \\
\text { in his club. He is very depressed and has come to you, the doctor in a corporate hospital accompanied by his } \\
\text { mother. Explore the scenario from the patient perspective using a role-play. } \\
\text { - Christina is a married lady living in Damascus, Syria. While going out to buy food for her family she was injured } \\
\text { in a bomb attack. Her right leg was badly damaged. She is admitted in your hospital and you are the treating } \\
\text { doctor. You have to amputate her limb from above the knee to save her life and gangrene and infection have set } \\
\text { in the limb. Explore the scenario from the patient perspective using a role-play. }\end{array}$ \\
\hline The doctor & $\begin{array}{l}\text { - Dr. Richard Darnell is an internal medicine specialist in Miami. He has a busy practice and runs a flourishing } \\
\text { nursing home. He is busy from morning till night in his practice. His wife is extremely unhappy. She accuses him } \\
\text { of having no time for her and the family. He is also accused of being money minded. She wants to divorce him. } \\
\text { Explore the situation using a role-play; } \\
\text { - Dr. Rudolph Valentino is a famous gynecologist in Los Angeles. He has a flourishing practice. Recently he was } \\
\text { accused of behaving improperly with a female patient. The patient's relatives are very angry and agitated and } \\
\text { have come to the hospital with the intention of manhandling the doctor and teaching him a lesson. Explore the } \\
\text { situation using a role-play. }\end{array}$ \\
\hline $\begin{array}{l}\text { The patient-doctor } \\
\text { relationship }\end{array}$ & $\begin{array}{l}\text { Dr. Richard is an Internal medicine specialist in Toronto. He has been treating a twenty-two year old college } \\
\text { student named Rachel for the last five years. The lady suffers from severe attacks of migraine and is on drug } \\
\text { prophylaxis. Richard has realized that he is in love with Rachel. He wants to live happily ever after with her. } \\
\text { However, he is not sure about whether it would be correct for a doctor to marry his young female patient. } \\
\text { Analyze the issues involved using a role play. } \\
\text { Dr. Jackson is a physician practicing in Jackson. Mississippi. He owns five automatic assault weapons and } \\
\text { despises blacks and Hispanics. Recently a Hispanic immigrant from Colombia has been allotted to his practice. } \\
\text { The lady is suffering from pain in the lower abdomen and speaks only Spanish. She has come to the clinic } \\
\text { accompanied by her brother in law who knows three-four words of English. Dr. Jackson is not happy that he has } \\
\text { a Hispanic patient and wants to re-allot her to some other doctor. Analyze the issues involved using a role play. }\end{array}$ \\
\hline $\begin{array}{l}\text { The medical } \\
\text { student }\end{array}$ & $\begin{array}{l}\text { - John Rambo is a medical student at XUSOM, Aruba. He is a talented musician and has won a number of prizes } \\
\text { during his school days. He wants to participate in an international medical student festival. However, his parents are } \\
\text { concerned about his poor academic performance. They have invested a lot of money in the education of their son. } \\
\text { They want him to concentrate on his studies and forget about playing the guitar. Explore the situation using a role play } \\
\text { - Roopa is a first semester medical student at XUSOM. She feels overwhelmed by the pressure of subjects in the } \\
\text { medical curriculum. She also believes herself to be in love with Julie, a beautiful lady studying in her class. The } \\
\text { lady however does not reciprocate Roopa's tender feelings. Roopa is very much disturbed and is neither able to } \\
\text { study nor sleep. Explore the situation using a role play. }\end{array}$ \\
\hline
\end{tabular}

are taught the basics of communicating with patients and get opportunities to practice these skills during visits to the family doctor's clinic, family health visits and health fairs organized by the school. They also practice these skills with simulated patients. Students learn to counsel simulated patients about management of their disease and drug and non-drug measures for their condition during pharmacology small group sessions.

In a medical school in India a humanities-based study module offered to sixth and eighth semester medical students utilized poems, short narratives, paintings, sketches and group discussions. ${ }^{11}$ At the Harvard Medical and Dental School in the United States, "Training the eye
Improving the art of physical diagnosis' was offered to interested preclinical students. Eight paired sessions of art observation sessions with didactic sessions integrating fine arts concepts with physical diagnosis topics were offered. ${ }^{12}$ Paintings have been used to teach reflective competence to medical students. ${ }^{13}$

Feedback from the participants was obtained at the end of each session. The form used to obtain feedback is shown in the Appendix. During each session the student participants were graded by the facilitator using a checklist which was partially derived from the instrument develop by Elizondo-Montemayor for assessment during problembased learning (PBL) sessions. ${ }^{14}$ At the end of the module students have to complete a reflective writing assignment. 


\begin{tabular}{|c|c|c|c|c|c|}
\hline \multicolumn{6}{|l|}{ Collaborative work } \\
\hline Works towards achievement of the group's learning goals... & 1 & 2 & 3 & 4 & 5 \\
\hline Shows effective interpersonal abilities & 1 & 2 & 3 & 4 & 5 \\
\hline Is interested in participating in the discussions & 1 & 2 & 3 & 4 & 5 \\
\hline Respects classmates' opinions & 1 & 2 & 3 & 4 & 5 \\
\hline Helps classmates who lag behind & 1 & 2 & 3 & 4 & 5 \\
\hline Gives feedback in a constructive and fraternal way & 1 & 2 & 3 & 4 & 5 \\
\hline Works as hard as the rest of his teammates & 1 & 2 & 3 & 4 & 5 \\
\hline \multicolumn{6}{|l|}{ Attitude during the module and Professionalism } \\
\hline Accepts feedback with openness & 1 & 2 & 3 & 4 & 5 \\
\hline Reacts positively to feedback and criticism & 1 & 2 & 3 & 4 & 5 \\
\hline Manages his/her impulsiveness adequately & 1 & 2 & 3 & 4 & 5 \\
\hline Stands up for his/her points of view... & 1 & 2 & 3 & 4 & 5 \\
\hline Makes an effort to modulate his/her behavior to circumstances & 1 & 2 & 3 & 4 & 5 \\
\hline Shows ability to change his/her point of view in light of new information given or obtained.... & 1 & 2 & 3 & 4 & 5 \\
\hline Attended every class and arrived on time & 1 & 2 & 3 & 4 & 5 \\
\hline Shows responsibility and commitment & 1 & 2 & 3 & 4 & 5 \\
\hline Is honest & 1 & 2 & 3 & 4 & 5 \\
\hline His/her appearance and clothing correspond with that of a medical professional & 1 & 2 & 3 & 4 & 5 \\
\hline S/he was creative & 1 & 2 & 3 & 4 & 5 \\
\hline $\mathrm{S} /$ he participated in group presentations, role plays and other activities & 1 & 2 & 3 & 4 & 5 \\
\hline S/he participated in open space & 1 & 2 & 3 & 4 & 5 \\
\hline S/he shows respect for the facilitators & 1 & 2 & 3 & 4 & 5 \\
\hline
\end{tabular}

Scale of 1 to 5 with 1 being very poor, $2=$ Poor, $3=$ Satisfactory, $4=$ Good, $5=$ Very good, $* *$ The instrument was developed by the author. Certain statements have been modified from an article on formative and summative assessment of the problem based learning process. ${ }^{14}$

\begin{tabular}{|c|c|c|c|c|c|}
\hline \multicolumn{6}{|c|}{$\begin{array}{l}\text { Appendix: Form used to obtain student } \\
\text { feedback at the conclusion of the sessions }\end{array}$} \\
\hline \multicolumn{6}{|l|}{ Feedback on the session } \\
\hline \multicolumn{6}{|l|}{ Name of the session } \\
\hline $\begin{array}{l}\text { The objectives of the session } \\
\text { were clearly delineated }\end{array}$ & 1 & 2 & 3 & 4 & 5 \\
\hline $\begin{array}{l}\text { The art excerpts were relevant to } \\
\text { the session objectives }\end{array}$ & 1 & 2 & 3 & 4 & 5 \\
\hline $\begin{array}{l}\text { The case scenarios were } \\
\text { relevant to the session objectives }\end{array}$ & 1 & 2 & 3 & 4 & 5 \\
\hline $\begin{array}{l}\text { The facilitators fulfilled their role } \\
\text { effectively }\end{array}$ & 1 & 2 & 3 & 4 & 5 \\
\hline $\begin{array}{l}\text { The session will be important to } \\
\text { my future practice }\end{array}$ & 1 & 2 & 3 & 4 & 5 \\
\hline $\begin{array}{l}\text { The facilitators succeeded in } \\
\text { creating a friendly atmosphere }\end{array}$ & 1 & 2 & 3 & 4 & 5 \\
\hline The group dynamics during the & 1 & 2 & 3 & 4 & 5 \\
\hline
\end{tabular}

session were to my satisfaction

I would rate the session ---------- on a scale of 1 to 10 (1 being the least and 10 being the most. Use whole numbers only).

Please score the session by marking the questions below where $1=$ Strongly disagree 2 =Disagree ${ }_{3}=$ Neutral $4=$ Agree 5 =Strongly agree

The grading scheme followed during the $\mathrm{MH}$ module is as follows: $50 \%$ of marks were decided on the basis of formative assessment by the facilitator using a structured checklist; $20 \%$ of total marks were decided on the basis of reflective writing assignments; $30 \%$ of marks were on the basis of professional attitudes, empathy and other skills shown during the history taking Objective Structured Clinical Examination (OSCE). Students should obtain over $70 \%$ of total marks to successfully complete the course.
The concept of empathy has had a difficult history and there have been disagreements and differences over the concept. ${ }^{15}$ A recent review ${ }^{15}$ had examined various aspects of empathy and tried to link it to neurobiology and recent knowledge of brain function. The concept of empathy is briefly introduced during the second $\mathrm{MH}$ session and explored using various activities. Students get opportunities to be empathetic to patients during early clinical exposure, family health visits and health fairs. I assess the ability of students to be empathetic to their patients, and make them comfortable during the OSCE. Among the parameters assessed were different process skills like opening, interviewing, listening, the doctorpatient relationship, closing and general organization of the interaction.

Student feedbacks obtained at the end of the inaugural $\mathrm{MH}$ module conducted during the Spring 13 semester was positive. ${ }^{4}$ The module was regarded as fun and engaging. Students identified most with the session on the medical student. Certain suggestions by the respondents were utilized during subsequent modules.

At present the module is being conducted for the recently joined first semester students during the Summer 14 semester. Thus the author has been successful in facilitating a $\mathrm{MH}$ module during four semesters at an offshore medical school in the Caribbean. The author's experiences would be of interest to medical educators interested in starting a MH module in the Caribbean, Nepal and other developing regions. 


\section{REFERENCES}

1. Shankar PR. A voluntary Medical Humanities module at the Manipal College of Medical Sciences, Pokhara, Nepal. Family Medicine 2008; 40:468-470.

2. Shankar PR. Developing and sustaining a medical humanities program at KIST Medical College, Nepal. Indian Journal of Medical Ethics 2013; 10:51-53.

3. Shankar P and Dubey AK. 'Modernizing' the Basic Sciences MD program at XUSOM, Aruba. WebmedCentral Medical Education 2013; 4(4):WMC004198.

4. Shankar PR and Dubey AK. Student feedback on an inaugural medical humanities module at XUSOM, Aruba. Education in Medicine Journal 2013; 5(4):e12-e20.

5. Shankar PR, Singh KK, Dhakal A, Shakya A and Piryani RM. Transcripts of a medical education in humanities module: selection of role plays. International Journal of User Driven Healthcare 2012; 2(3):63-76.

6. Shankar PR, Singh KK, Shakya A, Dhakal A and Piryani RM. Role plays used during a humanities in medicine module: Selected transcripts Part 2. International Journal of User-driven Healthcare (in press).

7. Manzoor I, Mukhtar F and Hashmi NR. Medical students' perspective about role-plays as a teaching strategy in community medicine. Journal of College of Physicians and Surgeons of Pakistan 2012; 22:222-225. doi: 04.2012/JCPSP.222225.

8. Simmenroth-Nayda A, Alt-Epping B and Gágyor I. Breaking bad news - an interdisciplinary curricular teachingconcept. GMS Zeitschrift für medizinische Ausbildung 2011; 28:Doc52.

9. Joyner B and Young L. Teaching medical students using role play: twelve tips for successful role plays. Medical Teacher 2006; 28:225-229.

10. Shankar PR and Piryani RM. Using paintings to explore the Medical Humanities in a Nepalese medical school. Medical Humanities 2009; 35:121-122.

11. Gurtoo A, Ranjan P, Sud R and Kumari A. A study of acceptability \& feasibility of integrating humanities based study modules in undergraduate curriculum. Indian Journal of Medical Research 2013; 137:197-202.

12. Naghshineh S, Hafler JP, Miller AR, Blanco MA, Lipsitz SR, Dubroff RP, et al. Formal art observation training improves medical students' visual diagnostic skills. Journal of General Internal Medicine 2008; 23:991-997.

13. Karkabi $\mathrm{K}$ and Cohen Castel $\mathrm{O}$. Teaching reflective competence in medical education using paintings. Medical Humanities 2011; 37:58-59.

14. Elizondo-Montemayor LL. Formative and summative assessment of the problem-based learning tutorial session using a criterionreferenced system. Journal of the International Association of Medical Science Educators 2004; 14:8-14.

15. Preston SD and de Waal FB. Empathy: Its ultimate and proximate bases. The Behavioral and Brain Sciences 2002; 25:1-20; discussion 20-71.

Authors Contribution:

PRS - Was involved in facilitating the sessions, conceptualizing and writing the paper and revising it for intellectual content. 